\title{
Pengaruh pemberian getah bonggol pisang (Musa paradisiaca var. sapientum L. Kuntze. AAB) terhadap penyembuhan luka sayat pada kulit tikus Wistar (Rattus norvegicus)
}

\author{
1'Jacqueline J. Wakkary \\ ${ }^{2}$ Meilany Durry \\ ${ }^{2}$ Carla Kairupan
}

\author{
${ }^{1}$ Kandidat Skripsi Fakultas Kedokteran Universitas Sam Ratulangi Manado \\ ${ }^{2}$ Bagian Patologi Anatomi Fakultas Kedokteran Universitas Sam Ratulangi Manado \\ Email: jacqueline_wakkary@yahoo.com
}

\begin{abstract}
Wound healing can be assisted by modern and traditional medicine. Banana stem sap is often used as a herbal remedy for wounds. The sap of banana stem contains saponins, flavonoids, anthraquinone, quinone, lectin, and tannins that are expected to promote wound healing. This study was aimed to determine the effect of banana stem sap on incised wound of the skin of Wistar rats. This was an experimental laboratory study. A total of 21 Wistar rats (Rattus norvegicus) were used in this study; one was used to obtain a normal skin sample, and the others were divided into control groups (A1 and B1) and treated groups (A2 and B2), five rats in each group. A 1-cm-skin incision was made on the back of each rat in all groups. The wounds of group A1 and B1 were untreated. In group A2 and B2, the wounds were applied with $0,5 \mathrm{ml}$ of banana stem sap (Musa paradisiaca var. sapientum L. Kuntze. AAB) twice a day. Macroscopic and microscopic examinations of the wounds were performed on day-5 (group A1 and A2) and day-14 (group B1 and B2). The results showed that, either macroscopically (wound area and crusting) or microscopically (crust, reepithelization, angiogenesis, proliferation of fibrous tissue and inflammatory cells), group A2 and B2 exhibited better wound healing compared with group A1 and B1. Conclusion: Better wound healing process in Wistar rats treated with banana stem sap on their insiced wounds compared to those that were untreated indicates that banana stem sap play distinct roles in promoting wound healing.
\end{abstract}

Keywords: wound healing, banana stem sap

\begin{abstract}
Abstrak: Penyembuhan luka dapat dibantu dengan pengobatan modern ataupun teradisional. Masyarakat awam sering menggunakan pengobatan tradisional salah satunya getah bonggol pisang untuk mengobati luka. Getah bonggol pisang mengandung saponin, flavonoid, antrakuinon, kuinon, laktin, dan tanin yang diduga dapat membantu penyembuhan luka. Penelitian ini bertujuan untuk mengetahui pengaruh pemberian getah bonggol pisang terhadap penyembuhan luka sayat pada kulit tikus wistar. Jenis penelitian ialah eksperimental laboratorik dengan subjek 21 ekor tikus Wistar (Rattus norvegicus) yang dibagi dalam: satu ekor tanpa perlakuan (sampel kulit normal) dan empat kelompok perlakuan (lima ekor tiap kelompok). Kelompok A1 dan B1 dibuat luka sayat \pm 1 $\mathrm{cm}$ pada daerah punggung tetapi tidak diolesi getah bonggol pisang (Musa paradisiaca var. sapientum L. Kuntze. AAB). Kelompok A2 dan B2 dibuat luka sayat kemudian diolesi getah bonggol pisang $0,5 \mathrm{ml}$ dua kali sehari. Penilaian dan pengambilan sampel jaringan kulit luka dilakukan pada hari ke-5 (kelompok A1 dan A2) dan hari ke-14 (kelompok B1 dan B2). Hasil penelitian menunjukkan bahwa gambaran penyembuhan luka, baik secara makroskopik (area permukaan luka dan kerak luka) maupun mikroskopik (krusta, reepitelisasi, angiogenesis, proliferasi jaringan ikat dan sel-sel radang) pada kelompok A2 dan B2 lebih baik dibandingkan dengan kelompok A1 dan B1. Simpulan: Ditemukan tanda-tanda penyembuhan luka yang lebih baik pada kelompok tikus Wistar yang diberikan getah bonggol pisang pada luka sayatnya dibandingkan dengan yang tidak diberikan, yang mengindikasikan bahwa getah bonggol pisang berperan khusus dalam membantu proses penyembuhan luka.
\end{abstract}

Kata kunci: penyembuhan luka, getah bonggol pisang 
Luka merupakan rusaknya kontinuitas jaringan oleh karena trauma dari benda tajam atau tumpul, perubahan suhu, kimiawi, listrik, radiasi, atau gigitan hewan. ${ }^{1}$ Ketika luka timbul, beberapa efek akan muncul diantaranya hilangnya seluruh atau sebagian fungsi organ, respon stres simpatis, kontaminasi bakteri dan kematian sel. ${ }^{2}$ Luka sayat merupakan salah satu jenis luka akibat benda atau alat yang bermata tajam yang terjadi dengan suatu tekanan ringan dan goresan pada permukaan tubuh. Luka sayat dapat ditemukan pada luka insisi akibat pembedahan dalam praktik ilmu bedah kedokteran. ${ }^{3}$

Penyembuhan luka terjadi melalui tiga fase, yaitu fase inflamasi, proliferasi dan remodeling jaringan. Penyembuhan luka dapat dibantu dengan pengobatan secara modern maupun tradisional. ${ }^{4}$ Masyarakat awam sering menggunakan tanaman obat tradisional, antara lain getah bonggol pisang untuk mengobati luka. Getah bonggol pisang mengandung serotonin, tannin, vitamin A, vitamin B dan vitamin C yang sangat esensial untuk tubuh dalam hubungannya dengan proses penyembuhan luka. ${ }^{1}$ Getah bonggol pisang juga mengandung saponin, antrakuinon, luinon dan laktin yang berfungsi sebagai antibiotik, mempercepat pertumbuhan sel dan meningkatkan pembentukan pembuluh darah sebagai respon terhadap proses penyembuhan luka. 5 Selain itu getah bonggol pisang mengandung flavonoid yang dapat menangkap radikal bebas untuk menghambat kerusakan sel dan sebagai antiinflamasi. ${ }^{6}$ Bukti empiris menunjukkan bahwa masyarakat di Indonesia, secara khusus di Manado dan sekitarnya, telah lama menggunakan getah bonggol pisang untuk pengobatan luka sayat pada kulit. Hal ini menarik untuk diteliti bagaimana pengaruh getah bonggol pisang terhadap penyembuhan luka sayat pada tikus Wistar.

\section{METODE PENELITIAN}

Jenis penelitian ini ialah eksperimental laboratorik yang dilakukan di Bagian Patologi Anatomi Fakultas Kedokteran Universitas Sam Ratulangi Manado pada periode Oktober-November 2016. Subjek penelitian yang digunakan ialah 21 ekor tikus galur Wistar (Rattus norvegicus) dalam keadaan sehat dan memiliki berat 200-250 gr.

Luka pada kulit dibuat sepanjang \pm 1 $\mathrm{cm}$ pada daerah punggung tikus wistar dengan menggunakan pisau bedah. Getah bonggol pisang (pisang raja; Musa paradisiaca var. sapientum L. Kuntze. $\mathrm{AAB}$ ), diperoleh dengan cara memotong pohon pisang pada bagian bonggol lalu diambil getahnya (setiap tiga hari sekali). Luka diiolesi getah $0,5 \mathrm{ml}$ dua kali sehari menggunakan lidi kapas lalu luka ditutup dengan kasa steril dan plester. Perbaikan jaringan kulit dinilai dengan melihat permukaan luka dan penyatuan tepi luka secara makroskopik, serta melihat adanya sel-sel radang, reepiteliasi, dan jaringan granulasi (fibroblas dan angiogenesis) pada gambaran mikroskopik.

Subjek penelitian dibagi dalam lima kelompok. Kelompok tanpa perlakuan 1 ekor untuk sampel kulit normal; kelompok perlakuan I (A1) tidak diberi getah bonggol pisang selama 4t hari; kelompok perlakuan II (A2) diberi getah bonggol pisang selama 4 hari; kelompok perlakuan III (B1) tidak diberi getah bonggol pisang selama 13 hari; kelompok perlakuan IV (B2) diberi getah bonggol pisang selama 13 hari. Penilaian secara makroskopik dan pengambilan sampel jaringan kulit untuk pemeriksaan secara mikroskopik dilakukan pada hari ke5 untuk kelompok A1 dan A2 dan hari ke14 untuk kelompok B1 dan B2.

\section{HASIL PENELITIAN}

\section{Gambaran makroskopik}

Luka kulit tikus wistar yang tidak diberi getah bonggol pisang pada hari ke-5 menunjukkan permukaan berwarna merah, terdapat bekuan darah, dan defek luka yang masih besar (Gambar 1) sedangkan luka yang diberi getah bonggol pisang terlihat permukaannya kering berwarna putih dan defek luka yang sudah mengecil (Gambar 2).

Luka kulit tikus wistar yang tidak diberi getah bonggol pisang pada hari ke- 
14 menunjukkan permukaan berwarna sedikit kemerahan, terdapat sedikit bekuan darah dan tampak defek luka yang kecil (Gambar 3). Luka yang diberi getah

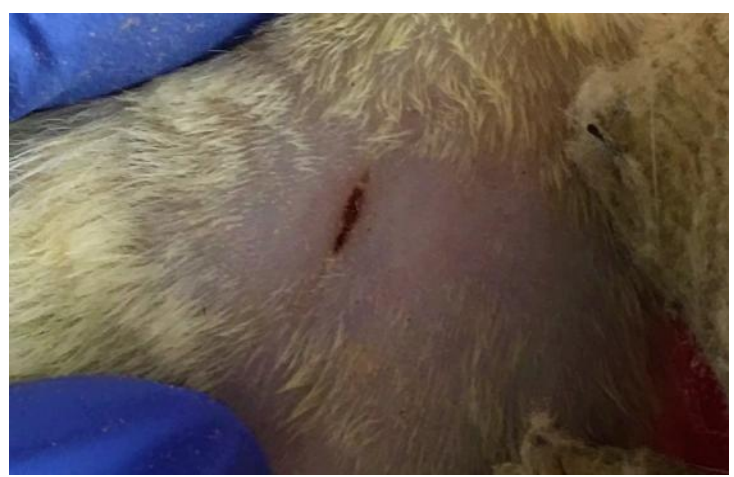

Gambar 1. Luka yang tidak diberi getah bonggol pisang. Terlihat permukaan luka berwarna merah, terdapat bekuan darah, dan defek luka yang lebar.

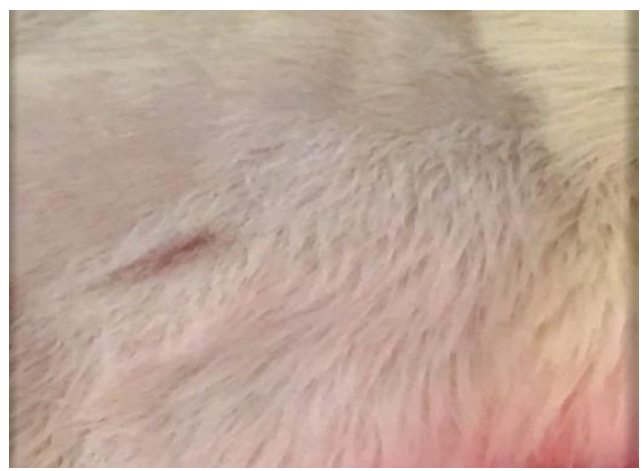

Gambar 3. Luka yang tidak diberi getah bonggol pisang. Terlihat permukaan luka berwarna sedikit kemerahan, terdapat sedikit bekuan darah dan tampak defek luka kecil.

\section{Gambaran mikroskopik}

Kulit tikus Wistar tanpa perlakuan menunjukkan gambaran kulit normal berupa bagian epidermis yang terdiri dari sel-sel epitel berlapis gepeng dan pada bagian dermis terdapat folikel rambut, kelenjar sebasea, dan pembuluh darah (Gambar 5).

Sampel jaringan kulit dari luka sayat pada tikus Wistar kelompok A1 memperlihatkan adanya krusta atau kerak luka yang tebal, reepitelisasi, serat kolagen dan banyak sel radang (Gambar 6a dan 6b) sedangkan pada kelompok A2 terlihat reepitelisasi sempurna/epitel gepeng sudah menutup bonggol pisang terlihat permukaan nya sudah kering berwarna putih dan defek luka yang sudah menghilang (Gambar 4).

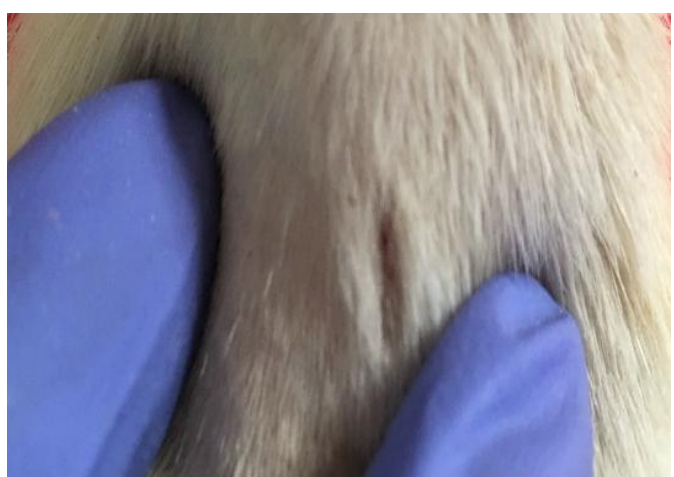

Gambar 2. Luka yang diberi getah bonggol pisang. Terlihat permukaan luka kering berwarna putih sedikit ditutupi bulu dan defek luka yang sudah lebih mengecil.

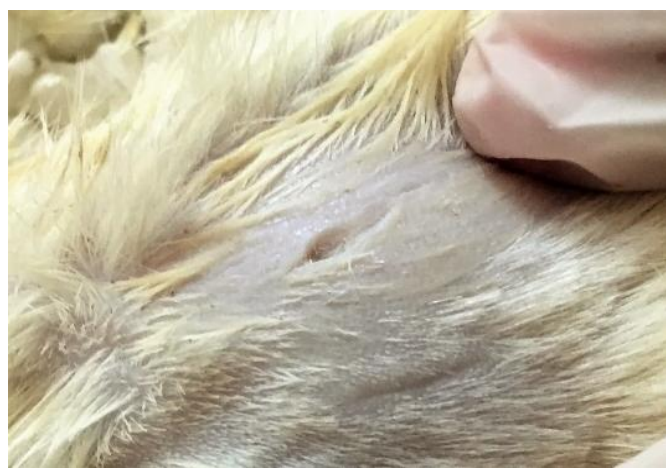

Gambar 4. Luka yang diberi getah bonggol pisang. Terlihat permukaan luka sudah kering berwarna putih dan defek luka yang sudah hilang.

pada permukaan luka, angio-genesis, krusta tipis, celah luka sudah terisi dengan jaringan granulasi yaitu fibroblas dan jaringan ikat kolagen (Gambar 7a dan 7b).

Jaringan kulit daerah sayatan dari tikus Wistar kelompok B1 menunjukkan sedikit sel radang, fibroblas, angiogenesis dan keratin yang menebal (Gambar 8a dan 8b) sedangkan pada kelompok B2 tampak epitel berlapis gepeng yang membentuk epidermis matang dengan ketebalan yang normal menutupi seluruh permukaan luka, penumpukan serat kolagen dan tidak ditemukan sel-sel radang (Gambar 9a dan 9b). 


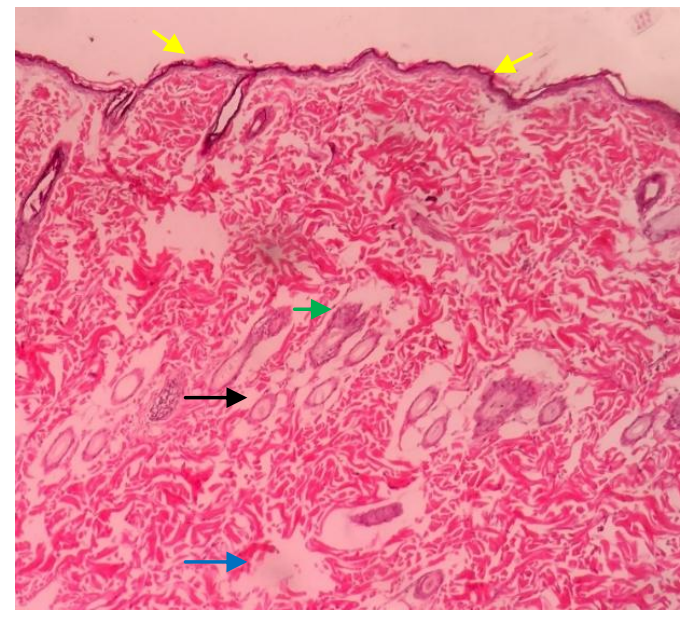

Gambar 5. Gambaran normal kulit tikus wistar (kelompok tanpa perlakuan 14 hari). Tampak epitel berlapis gepeng (panah kuning), folikel rambut (panah hitam), kelenjar sebasea (panah hijau) dan pembuluh darah (panah biru). 100x

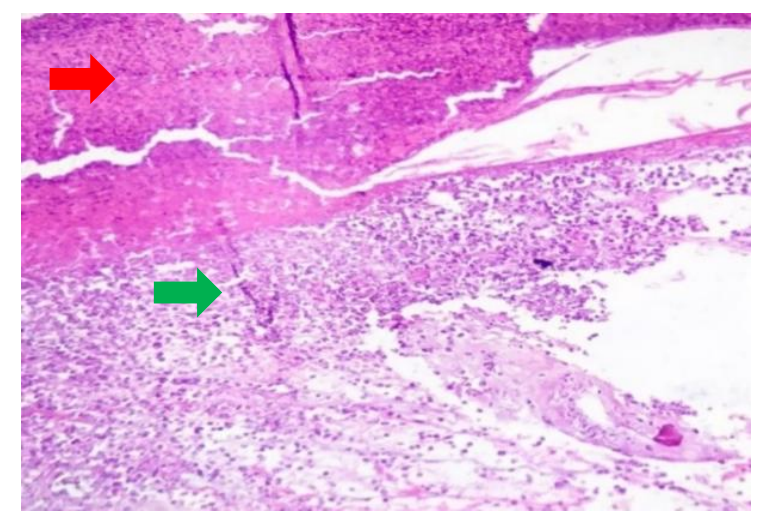

Gambar 6a. Penyembuhan luka tanpa getah bonggol pisang hari ke-5. Terlihat adanya krusta atau kerak luka (panah merah) dan terdapat sel radang (panah hijau). 400x

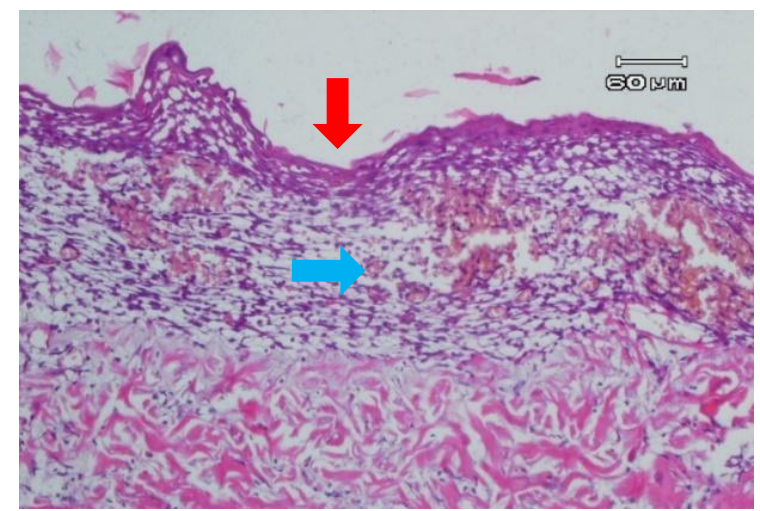

Gambar 7a. Penyembuhan luka yang diberi getah bonggol pisang hari ke-5. Terlihat reepitelisasi sempurna/epitel yang sudah menutup (panah merah), dan angiogenesis (panah biru). 400x

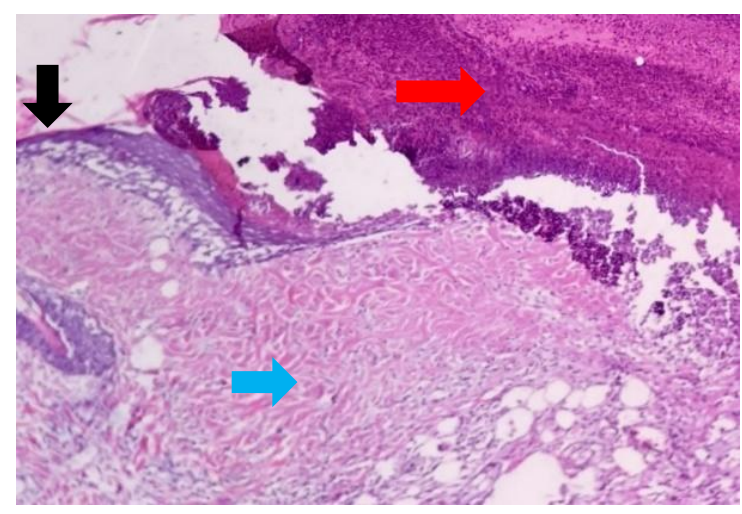

Gambar 6b. Penyembuhan luka tanpa getah bonggol pisang hari ke-5. Terlihat adanya krusta atau kerak luka (panah merah), reepitelisasi (panah hitam) dan serat kolagen (panah biru). 400x

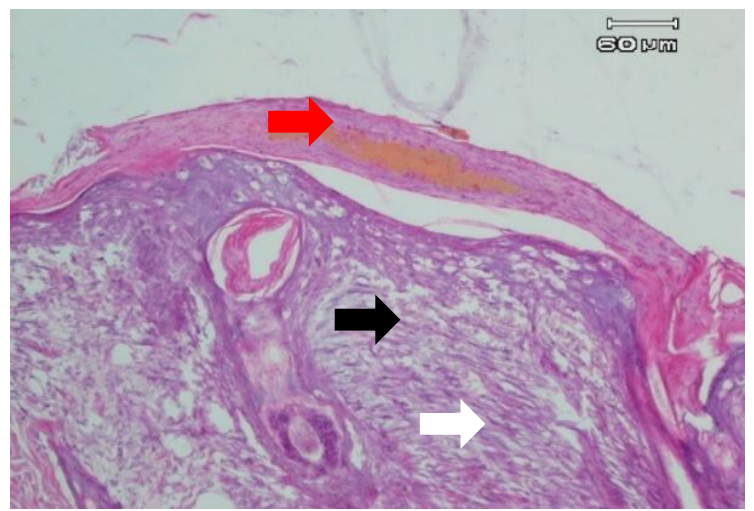

Gambar 7b. Penyembuhan luka yang diberi getah bonggol pisang hari ke-5. Terlihat krusta (panah merah), celah luka sudah terisi dengan jaringan granulasi yaitu fibroblas (panah hitam) dan jaringan ikat kolagen (panah putih). 400x 


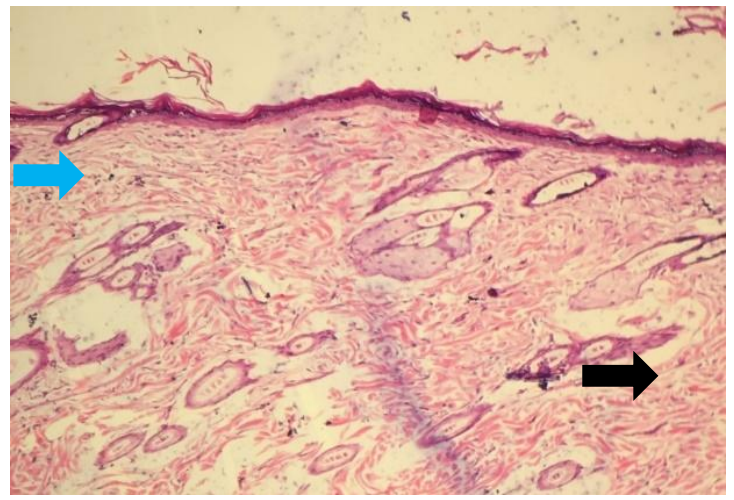

Gambar 8a. Penyembuhan luka yang tidak diberi getah bonggol pisang hari ke-14. Terlihat angiogenesis (panah hitam), fibroblas (panah biru). 400x

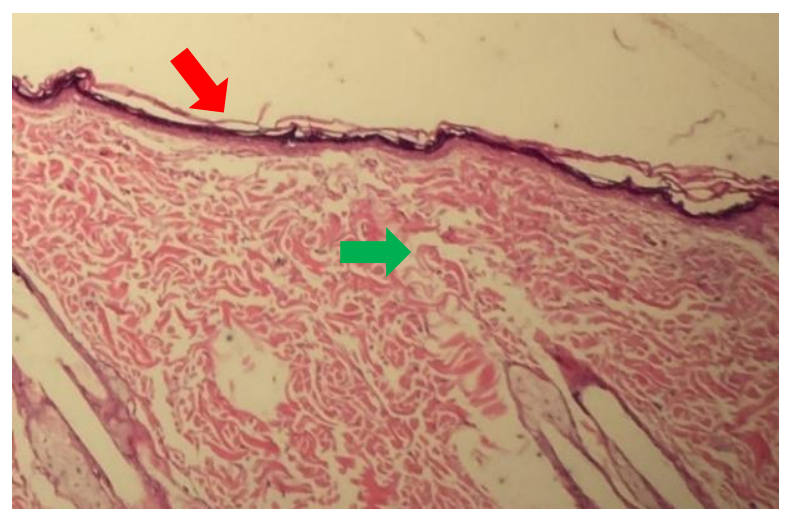

Gambar 9a. Penyembuhan luka yang diberi getah bonggol pisang hari ke-14. Terlihat epitel menutup sempurna (panah merah) dan serat kolagen (panah hijau). 400x

\section{BAHASAN}

Getah bonggol pisang merupakan salah satu tanaman obat tradisional yang sering digunakan oleh masyarakat untuk mempercepat penyembuhan luka. Penelitian ini memberikan informasi dan gambaran tentang pengaruh getah bonggol pisang (Musa paradisiaca var. sapientum L. Kuntze. AAB) terhadap penyembuhan luka sayat yang dilakukan pada hewan uji tikus wistar (Rattus norvegicus).

Hasil penelitian ini menunjukkan perbedaan dalam proses penyembuhan luka sayat kulit tikus Wistar yang diberi (A2) dan tidak diberi (A1) getah bonggol pisang. Berdasarkan pengamatan makroskopik hari ke-5 setelah insisi kulit, luka yang tidak diberi getah bonggol pisang tampak permukaan masih berwarna merah yang belum menutup sempurna serta terdapat

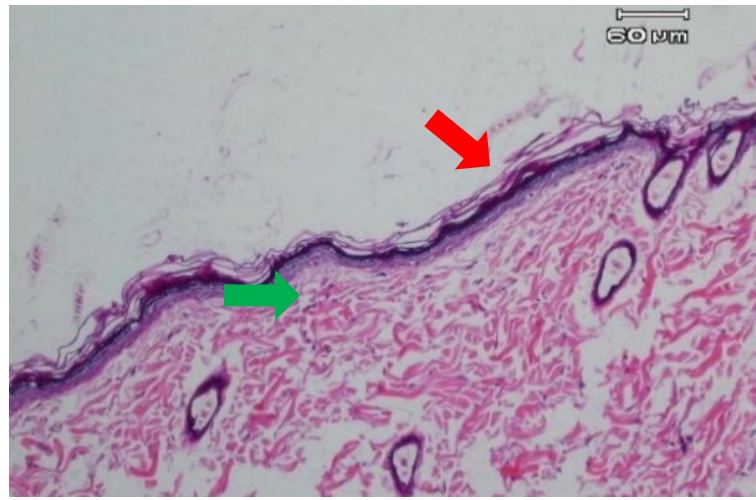

Gambar 8b. Penyembuhan luka yang tidak diberi getah bonggol pisang hari ke-14. Terlihat sedikit sel radang (panah hijau) dan keratin yamg menebal (panah merah). 400x

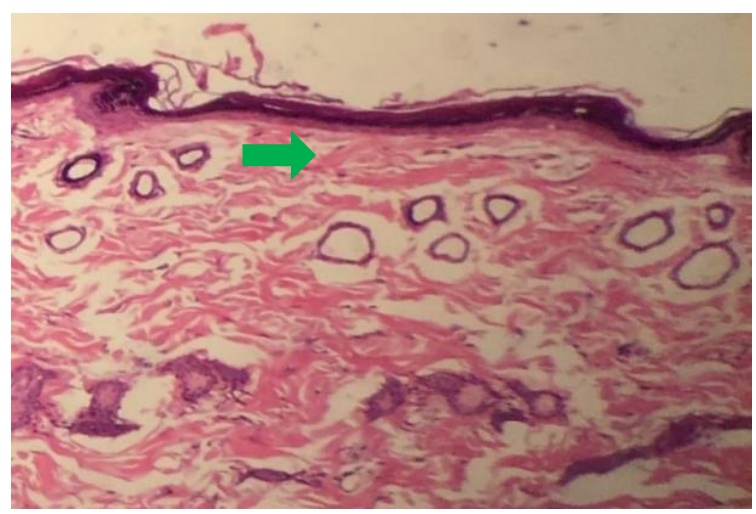

Gambar 9b. Penyembuhan luka yang diberi getah bonggol pisang hari ke-14. Terlihat penumpukan serat kolagen (panah hijau). 400x

bekuan darah juga krusta (Gambar 1); sedangkan luka yang diberi getah bonggol pisang kelihatan lebih baik, dengan permukaan dan tepi luka sudah mengering dan berwarna putih serta sebagian luka sudah tertutup (Gambar 2). Gambaran makroskopik ini ditunjang oleh gambaran mikroskopik, yaitu luka yang tidak diberi getah bonggol pisang (Gambar 6a dan 6b) menunjukkan banyak sel radang, adanya krusta atau kerak luka yang besar meskipun sudah ada reepitelisasi, jaringan granulasi dan penumpukkan serat kolagen; sedangkan luka yang diberi getah bonggol pisang (Gambar 7a dan 7b) memperlihatkan permukaan luka/epidermis yang sudah menutup dan proliferasi epitel berlapis gepeng, angiogenesis, krusta yang sudah mulai menghilang, celah luka sudah terisi dengan jaringan granulasi yaitu fibroblas 
dan jaringan ikat kolagen yang menjadi padat serta mulai menyambung ditepi insisi (bandingkan Gambar 6a, 6b dan 7a, 7b).

Pada proses penyembuhan luka fisiologik, gambaran mikroskopik yang dapat dilihat pada hari ke-5 yaitu ruang insisi terisi jaringan granulasi yang terdiri dari jaringan penunjang yang kaya vaskuler, mengandung kapiler-kapiler baru, kaya fibroblas dan berbagai sel radang. ${ }^{7}$ Makrofag berfungsi membersihkan jaringan-jaringan mati dan menyekresi faktor pertumbuhan seperti epidermal growth factor (EGF) yang merangsang pembelahan sel epitel dan fibroblast, fibroblast growth factor (FGF) menstimulasi pertumbuhan kapiler dan mitogenik untuk fibroblas, sel endotel dan sel otot polos, serta vascular endothelial growth factor (VEGF) yang dapat meningkatkan angiogenesis pada penyembuhan luka. Hiperplasia epitel yang terlihat merupakan hiperplasia fisiologik sebagai kompensasi saat sebagian jaringan yang dibuang, terputus atau sakit. Hiperplasia juga merupakan respon kritis sel jaringan ikat padat penyembuhan luka, dimana pada keadaan tersebut fibroblas yang distimulasi faktor pertumbuhan dan pembuluh darah berploriferasi untuk mempermudah proses perbaikan. ${ }^{8}$ Peningkatan fibroblas dan angiogenesis yang terlihat pada luka sayat yang diberi getah bonggol pisang dalam penelitian ini dapat juga disebabkan oleh bahan yang terkandung dalam getah bonggol pisang antara lain saponin. Saponin dapat memacu pembentukan fibroblas untuk sintesis kolagen dan meningkatkan pembentukan pembuluh darah baru sehingga pasokan oksigen dan nutrisi pada luka lebih banyak dan penyembuhan dapat terjadi lebih cepat. ${ }^{9}$ Disamping itu getah bonggol pisang juga mengandung flavonoid yang memiliki khasiat sebagai antioksidan dan antiflamasi sehingga dapat membantu proses penyembuhan luka dan menghambat kerusakan sel. ${ }^{10}$ Antrakuinon sebagai antibakteri dapat memusnahkan bakteri yang masuk kedalam luka dengan cara membunuh atau menghambat pertumbuhan mikroorganisme pada jaringan yang hidup seperti pada permukaan kulit dan membran mukosa. ${ }^{11}$

Efek pemberian getah bonggol pisang terhadap penyembuhan luka sayat pada kulit tikus wistar juga jelas terlihat pada pemeriksaan hari ke-14 (perlakuan B1 dan B2). Secara makroskopik, luka yang tidak diberi getah bonggol pisang (Gambar 4) tampak sudah mengecil namun masih terlihat berwarna kemerahan dengan sedikit bekuan darah. Gambaran yang berbeda terlihat pada luka yang diberi getah bonggol pisang (Gambar 5); penyembuhan luka sudah hampir sempurna, permukaan luka yang sudah tampak kering berwarna putih, dan defek luka yang sudah hilang. Secara mikroskopik luka yang tidak diberi getah bonggol pisang (Gambar 8a dan 8b) menunjukkan epitel permukaan sudah menutup sempurna namun masih terdapat sedikit sel radang dan angiogenesis, sedangkan pada luka yang diberi getah bonggol pisang (Gambar 9a dan 9b) tampak epitel berlapis gepeng yang matang dan sudah terbentuk sempurna menutupi seluruh permukaan luka serta terdapat penumpukkan kolagen; terlihat mirip dengan kulit normal. Berdasarkan teori pada hari ke-14 proses penyembuhan luka, memperlihatkan penumpukkan kolagen dan poliferasi fibroblas masih berlanjut. Adanya infiltrasi leukosit, edema dan vaskularisasi yang awalnya meningkat sebagian besar akan hilang, adanya proliferasi fibroblas yang masih berlangsung, dan infiltrasi sel-sel radang sebagian besar menghilang. ${ }^{8}$

Penelitian ini menunjukkan bahwa penggunaan getah bonggol pisang dapat membantu penyembuhan luka mulai dari fase peradangan sampai fase remodeling. Hal ini sejalan dengan hasil penelitian Budi $^{12}$ bahwa kandungan flavonoid, saponin dan tanin dalam getah bonggol pisang memiliki fungsi sebagai antioksidan, proangiogenesis, serta dapat meningkatkan pasokan oksigen dan juga nutrisi pada kulit daerah perlukaan.

Keterbatasan penelitian ini ialah jumlah subjek penelitian maupun referensi mengenai kandungan farmakokinetik dan 
farmakodinamik dari bahan yang terkandung dalam getah bonggol pisang masih kurang

\section{SIMPULAN}

Dari hasil penelitian ini dapat disimpulkan bahwa terdapat tanda-tanda proses penyembuhan luka yang lebih baik pada kelompok tikus Wistar yang diberikan getah bonggol pisang pada luka sayatnya dibandingkan dengan yang tidak diberikan; hal ini mengindikasikan bahwa getah bonggol pisang berperan khusus dalam membantu proses penyembuhan luka.

\section{SARAN}

Perlunya dilakukan penelitian yang sama dengan jumlah subjek penelitian yang lebih banyak untuk mendapatkan hasil yang lebih akurat.

1. Perlu dilakukan penelitian untuk mengetahui lebih lanjut apakah getah bonggol pisang memiliki efek sebagai antibakteri pada luka yang terinfeksi.

2. Perlu penambahan jumlah sampel untuk penelitian agar dapat dilakukan uji statistik.

\section{DAFTAR PUSTAKA}

1. Reksoprodjo S. Plastik: penyembuhan luka. In: Reksoprodjo S, Pusponegoro A, Kartono D, Hutagalung EU, Sumardi R, Lutfia CS, Ramli M, et al, editors. Kumpulan Kuliah Ilmu Bedah. Jakarta: Fakultas Kedokteran Universitas Indonesia, 2012; p. 387.

2. Sebastion DC. Penyembuhan dan penatalaksaan luka. In: Adriando $\mathrm{P}$, Timan IS, Oswari J, ahli bahasa, editors. Buku Ajar Bedah Bagian 1. Jakarta: EGC, 1995; p. 146.

3. Hoediyanto. Forensik molekuler. In: Apuranto H, Hoediyanto, editors. Buku Ajar Ilmu Kedokteran Forensik dan Medikolegal (7th ed). Surabaya: Departemen Ilmu Kedokteran Forensik dan Medikolegal Fakultas Kedokteran Universitas Airlangga, 2010; p. 86-94.
4. Hasibuan LY, Soedjana H, Bisono. Luka. In: Sjamsuhidajat R, Karnadihardja W, Prasetyono TOH, Rudiman R, editors. Buku Ajar Ilmu Bedah (3rd ed). Jakarta: EGC, 2010; p. 95-7.

5. Priosoeryanto, Pontjo B, Putriyanda, Listayanti N, Juniantito AR. The efect of ambon banana stem sap (musa paradisiaca formatypica) on the acceleration of wound healing process in mice (mus musculus albinus). Bogor: Faculty of Veterinary Medicine, Bogor Agricultural University (IPB), 2007; p. 36.

6. Weremfo A, Adinortey MB, Pappoe ANM. Haemostatic effect of the stem juice of musa paradisiaca $\mathrm{L}$. (musaceae). Advance in Biological Research; 2011;5(4):190-2.

7. Sudiono J, Kurniadhi B, Hendrawan A, Djimantoro B. Degenerasi mukoid epitelial. In: Sudiono J, editor. Penuntun Praktikum Patologi Anatomi. Jakarta: EGC, 2001; p. 66-8.

8. Mitchell RN, Cotran RS. Pemulihan jaringan: regenerasi dan fibrosis sel. In: Hartanto $\mathrm{H}$, Darmaniah N, Asroruddin $\mathrm{M}$, editors. Buku Ajar Patologi (7th ed). Jakarta: EGC, 2007; p. 79-81.

9. Morisaki N, Watanabe S, Tezuka M, Zenibayashi M, Shiina R, Koyama N, et al. Mechanism of angiogenic effects of saponin from ginseng Radix rubra in human umbilical vein endothelial cells. British Journal of Pharmacology. 1995; 115(7):1188-93.

10. Oktiarni D, Manaf S, Suripno. Pengujian ekstrak daun jambu biji (Psidium guajava Linn) terhadap penyembuhan luka bakar pada mencit (mus musculus). GRADIEN Journal. 2012;8(1):752-5.

11. Dzulkarnain. Tanaman Obat Keluarga (Cetakan II). Jakarta: PT Intisari Mediatama, 1998.

12. Budi HS, Kriswandini IL, Iswara AD. Antioxidant activity test on ambonese banana stem sap (Musa parasidiaca var. sapientum). Dental Journal. 2015; 48(4):188-92. 